\title{
Insects associated with sweet fennel: beneficial visitors attracted by a generalist plant
}

\author{
Oksana Skaldina ${ }^{1}$ (1)
}

Received: 6 July 2019 / Accepted: 7 March 2020 / Published online: 21 March 2020

(c) The Author(s) 2020

\begin{abstract}
Insects provide key ecosystem services such as pollination, dung burial, soil enhancement, and pest control. Global insect decline requires restoration of the plant-insect mutualistic interactions. By using magnet plants, it is possible to supply beneficial insects with better resource availability and create more sustainable habitats. Current management practices recommend using Umbellifers (Apiales, Apiaceae) in restoration projects. However, analyses of the structure and dynamics of entomofauna associated with this plant family is needed to facilitate practical actions. Here the attention is focused on species composition and seasonal dynamics of beneficial insects associated with sweet fennel Foeniculum vulgare (Apiaceae, Umbelliferae) in Crimea. A 2-year sampling campaign identified 60 insect species from 40 genera across 20 families and four orders: Hymenoptera, Diptera, Coleoptera, and Neuroptera. These insects represented the groups such as social wasps, bees, ants, bumble bees, potter wasps, beetles, lacewings, mud daubers, tachinid flies, and hoverflies. Social wasps and hoverflies dominated in sample collections. Most of insects collected benefit ecosystems and provide essential ecosystem services. During fennel's flowering season, the number of visits by bumble bees, beetles, bees. and wasps decreased. Contrastingly, dipterans visitation increased towards the end of the season. Such trends might be explained with fennel's functional protandry, bias in nectar production between male and female flower stages, and insects' feeding preferences. $F$. vulgare attracts a diverse assemblage of beneficial insects and consequently can be recommended as a magnet species. When aiming to attract specific insect groups, the seasonal dynamics of fennel's associated entomofauna should be considered.
\end{abstract}

Keywords Ecosystem services $\cdot$ Foeniculum vulgare $\cdot$ Insect attraction $\cdot$ Magnet plants $\cdot$ Pollinators $\cdot$ Predators

\section{Introduction}

Insects provide ecosystem services such as food provisioning, recycling organic matter, biological control, and plant pollination (Noriega et al. 2018). The current phenomenon of global insect decline (Sánchez-Bayo and Wyckhuys 2019) and, more specifically, the decline of pollinators is primary caused by intensive agriculture, habitat conversion, and environmental chemicalization (Potts et al. 2010). Modern agriculture is largely dependent on managed pollinators. While causes of the decline in managed pollinators are being

Handling Editor: Jarmo K. Holopainen.

Oksana Skaldina

oksana.skaldina@uef.fi

1 Department of Environmental and Biological Sciences, University of Eastern Finland, P.O. Box 1627,

70211 Kuopio, Finland elucidated, more investigations underlying the decrease in wild pollinators are needed. Primarily wild pollinators, unlike their managed counterpart, provide ecosystem services (Allsopp et al. 2008). Effective crop diversification schemes are a promising alternative to pesticide-oriented agricultural practice, as they can suppress herbivores, increase the abundance of natural enemies and decrease insect-related crop damage (Scherr and McNeely 2008; Letourneau et al. 2011). Increasing plant biodiversity and creation of wildflower strips is a key tool for the conservation of beneficial insects in commercial ecosystems (Campbell et al. 2012). Flowing plants within these strips, benefit insects providing essential ecosystem services, especially in resource poor ecosystems. Especially attractive plants within these wildflower strips have been coined "magnet" (Laverty 1992) or "framework" plants (Menz et al. 2011). Frequencydependent pollinator visitation increases in species-rich floral mixtures and general pollinator diversity may contribute to pollination service stability (Ghazoul 2006). Plants can 
compete for pollinators, and in small or isolated populations, this can result in Allee effects (Courchamp et al. 2008). Alternatively, instead of competition, co-flowering plants may facilitate pollination, especially in species-rich swards (Ghazoul 2006). Pollinators can discriminate between flowers, but if more generalist pollinators are attracted to a specific habitat, then rare or less rewarded plant species receive increased attraction of pollinators to highly rewarding "magnet" species. Furthermore, greater biodiversity of plants favors pest reduction and supports the natural enemy hypothesis (Altieri 1991). However, diverse but arbitrarily composed floral vegetation plots may result in an increase of pest populations or repellence of beneficial insects from the target plant species or specific crop (Wäckers and van Rijn 2012). Therefore, identifying appropriate 'magnet' species and their associated entomofauna when developing eco-agricultural and mixed-agricultural landscapes (Scherr and McNeely 2008) will enhance biodiversity and inform biodiversity management practice.

Plants within the carrot family (Apiales, Apiaceae, Umbelliferae; hereafter umbellifers) are associated with diverse insect visitors and are often proposed as magnet species in restoration projects (Zych et al. 2007). Experimental removal of umbellifers led to a decline in the specialization of pollinator networks (Goldstein and Zych 2016). Despite much general knowledge regarding entomofauna associated with umbellifers, species-specific information is scarce. As mentioned by Memmott (1999), the proper understanding of the insect community structure requires an assessment of the all possible flower visitors. Umbellifers are often used in restoration projects due to the general knowledge that they attract a diversity of insects. In the current paper the data on the species composition and dynamics of insects, associated with umbellifer plant, $F$. vulgare have been discussed.

\section{Materials and methods}

\section{Study species}

Originating in the Mediterranean, sweet fennel Foeniculum vulgare (Miller, 1768) has been naturalized in many regions of the world. It is currently cultivated in Europe, Asia and North America (Badgujar et al. 2014). In its native range, it occurs in three varieties: as an annual, biennial or perennial herb (Piccaglia and Marotti 2001). F. vulgare has an erect hollow stem, up to $2.5 \mathrm{~m}$ in high, greenish-yellow flowers and feathery leaves. Its dichogamous flowers are arranged into large inflorescences-compound umbels of different orders. Like many other umbellifers (Stpiczyńska et al. 2015), within individual flower fennel demonstrates functional protandry. At first, flowers pass through a male functional stage with active anthers and then through the female functional stage with active stigma. In this group of plants, protandry is characterized by centripetal development when earlier anthers occur in outer flowers of the compound umbels and outer umbellets within an umbel (Webb 1981).

\section{Study area}

The data collection and field observations were performed in 2009-2010 years in the vicinities of Nikitsky Botanical Garden, Yalta, Crimea $\left(44.50^{\circ} \mathrm{N}, 34.23^{\circ} \mathrm{E}\right)$. The study area was previously (approximately 20 years) an experimental field of essential oil plants. Naturally recruited fennel shrubs were growing non-uniformly-denser in some areas and more sparsely in the others. During the $F$. vulgare flowering period, other the plants, including Italian strawflower (Helichrysum italicum), oregano (Origanum vulgare), thyme (Thymus vulgaris), Puget Sound gumweed (Grindelia integrifolia), lavender (Lavandula angustifolia) were also in bloom. The area of the meadow plot, where the observations were conducted, was approximately $11200 \mathrm{~m}^{2}$.

\section{Insect sampling and identification}

Insect sampling was conducted in one study site (meadow of essential oil plants) during the summer (June-August) in 2009 and 2010. These data were pooled and analyzed together as the overall insect diversity rather than betweenyear variations was the study target. Four walking transects (100-130 $\mathrm{m}$ in length) were selected in both years. The average distance (Mean \pm SD) between transects was $15 \pm 3.2 \mathrm{~m}$. In 2009, insects were collected using the hand net within 3-days intervals during the peak flowering stage of $F$. vulgare in July. In 2010, insects were sampled via the same method but within 3- to 5-day intervals during the entire blooming period of sweet fennel, lasting from the first half of June (10th of June) till the first half of August (16 th of August). Only those insects, visited flowering umbels for pollen and nectar collection were counted during subsequent statistical analyses. Pests, such as sucking bugs, caterpillars and aphids were collected, but not statistically assessed. Hand-net collection was performed via steady pace walking and insect sampling from random flowering fennel umbels on the sides of the transect. That was conducted two times per day ( $1 \mathrm{~h}$ per one-time sampling) in between 10 and $12 \mathrm{AM}$ and in between 2 and 4 PM. While collecting insects, the flowering stage of an umbel (male or female) was recorded. For the analysis, a species was defined as a visitor of both functional stages only if it was collected from both male and female umbels at least one time. Collected insects were stored in a $90 \%$ alcohol and further identified to species level with insect identification guides. The insects were assessed to morphotype such as: $(a)$ bee; $(b)$ bumble bee; $(c)$ social wasp; $(d)$ potter wasp; $(e)$ parasitic wasp; $(f)$ 
mud dauber; $(g)$ sphecoid wasp; $(h)$ hoverfly; $(i)$ tachinid fly; $(j)$ beetle; $(k)$ net wing. For the further statistical analyses this categorization was simplified and some insect categories (e.g., net wings) were discarded due to low number of registered visitors. As the sampling campaign was performed at a single study site, the further results should be considered at the local level and can't be extrapolated to the whole Crimea.

\section{Analyses of seasonal dynamics of insects, associated with fennel}

In 2010 ten focal plants were selected along each transect and used to investigate the seasonal dynamics of insect visitors. Five-minute focal observations were made for each control plant through the entire flowering season from the 10th of June till 16th of August in 2-5 days intervals. The flowering stage (male/female) of the umbels was registered for each observation, which allowed the further calculation of the population-level duration differences between stages. Insect visitors were accessed to morphotype (as described further) in 5-min sets of observations on a random umbel of each plant. Only umbels of the first and second orders were selected for observations. Each set of observations $(n=40$ plants per set) was performed during day peak activity between $10 \mathrm{AM}$ to $4 \mathrm{PM}$ in 1 day. Because the fennel's population in that year was monitored already from the beginning of June, the day when the first umbel started to bloom (10th of June) was selected as a starting point for the beginning of the flowering season. The total time of observations comprised $50 \mathrm{~h}$ and 600 observations. One observation was considered as registration of all insect visitors for $5 \mathrm{~min}$ at the one umbel (1st or 2 nd order) of a fennel plant.

Five merged insect morphotypes were considered when analyzing seasonal dynamics of entomofauna associated with $F$. vulgare: (1) bees, including honey bee and wild bees; (2) bumble bees; (3) wasps, including social, solitary, sphecoid, spider- and parasitic wasps; (4) flies, including hoverflies, flesh and tachinid flies; (5) beetles. Although belonging to the bees' group, bumble bees were not merged with bees. Already during the preliminary data collection stage, they were noticed to visit only umbels of the male functional stage. The other reason for quantifying bumble bees separately was the potential need for such information for practitioners, as bumble bees represent one of the most common groups of managed pollinators.

\section{Statistics}

The overall diversity of insects attracted by $F$. vulgare (sample data) was analyzed using Simpson's diversity index. The proportion of each insect group in the collected sample set was estimated in percentages. Further statistical analyses were carried out using statistical software SAS version 9.4
(SAS Institute, Cary, NC, USA). Population-level differences in duration of male and female functional flowering stage (number of days since the start of the fennel's flowering season) of fennel ( $n=40$ plants) were analyzed using $t$-Test for independent samples with Satterthwaite approximation of degrees of freedom. The number of days was used as a continuous dependent variable and umbel functional stage was used as a categorical independent variable with two levels (1-male; 2 -female). Also, $t$-Tests were used to assess the difference in insect visitation between functional stages. The seasonal dynamics of fennel-associated entomofauna was analyzed using Generalized Linear Model (GLM procedure Genmod in SAS) using a Poisson error distribution and log link function. This model was selected because all dependent variables (insect morphotypes) did not fit requirements for normally distributed data. Besides, the model was chosen because each insect morphotype was a count-type variable. The duration of the flowering season (number of days from the beginning of the flowering season) was used as an explanatory variable in GLM. Transect id was not included as a random factor into the model as each of four transects was selected randomly in each sampling occasion in the same field, so no generic factor was expected.

\section{Results}

\section{Diversity of insect visitors on fennel}

A total of 316 insect specimens, representing 4 orders, 40 genera, 20 families and 60 distinct species, were collected from flowering umbels of $F$. vulgare were over the 2-year study (Table 1). Simpson's index revealed a high diversity of insects, visiting fennel $(D=0.09)$. The data obtained after species identification demonstrated that in Crimea fennelassociated entomofauna comprised the groups of insects such as social wasps, hoverflies, beetles, bumble bees, potter wasps, mud daubers, tachinid flies, sphecoid and parasitic wasps. Social wasps and hoverflies dominated in sample collections, followed by bees, beetles and bumble bees (Fig. 1). Many groups of insect species attended both male and female functional stages of fennels' umbels. However, some of those, like bumble bees, preferred visiting only male flowers and were not found visiting umbels with the female functional stage.

\section{Seasonal dynamics of fennel-associated entomofauna}

Because of fennel's functional protandry, it was important to determine if there was a difference in the duration of male and female flowering stages at the population level. In 2010 
Table 1 Different groups of beneficial insect species attracted by F.vulgare in Crimea

\begin{tabular}{|c|c|c|c|c|c|}
\hline \multirow[t]{2}{*}{ Insect group } & \multirow[t]{2}{*}{ Species name } & \multirow[t]{2}{*}{$n$} & \multicolumn{3}{|c|}{$\begin{array}{l}\text { Captured on the functional } \\
\text { stage }\end{array}$} \\
\hline & & & Male & Female & Both \\
\hline \multirow{8}{*}{$\begin{array}{l}\text { Social wasps } \\
\text { (Vespidae) }\end{array}$} & Polistes nimpha & 14 & & & $\times$ \\
\hline & Polistes dominula & 28 & & & $\times$ \\
\hline & Polistes gallicus & 13 & & & $x$ \\
\hline & Vespula germanica & 6 & & & $\times$ \\
\hline & Vespula vulgaris & 5 & & & $x$ \\
\hline & Vespula rufa & 3 & & & $x$ \\
\hline & Dolichovespula sylvestris & 1 & $x$ & & \\
\hline & Dolichovespula media & 2 & $x$ & & \\
\hline $\begin{array}{l}\text { Ants } \\
\text { (Formicidae) }\end{array}$ & Formica cinerea & 2 & $x$ & & \\
\hline \multirow{7}{*}{$\begin{array}{l}\text { Potter wasps } \\
\text { (Eumenidae) }\end{array}$} & Eumenes papillarius & 1 & $\times$ & & \\
\hline & Eumenes mediterraneus & 5 & & & $x$ \\
\hline & Eumenes coarctatus & 4 & $x$ & & \\
\hline & Katamenes dimidiatus & 1 & $x$ & & \\
\hline & Euodynerus dantici & 4 & $x$ & & \\
\hline & Syneuodynerus egregius & 1 & $x$ & & \\
\hline & Ancistrocerus gazella & 1 & $\times$ & & \\
\hline \multirow[t]{3}{*}{ Mud daubers (Sphecidae) } & Sceliphron destillatorium & 11 & & & $\times$ \\
\hline & Sceliphron caementarium & 5 & & & $\times$ \\
\hline & Sceliphron curvatum & 1 & $x$ & & \\
\hline \multirow[t]{3}{*}{ Sphecoid wasps (Sphecidae) } & Philanthus triangulum & 5 & & & $\times$ \\
\hline & Larra anathema & 1 & $x$ & & \\
\hline & Cerceris arenaria & 6 & $\times$ & & \\
\hline Spider wasps (Pompilidae) & Batozonellus lacerticida & 1 & $\times$ & & \\
\hline \multirow[t]{3}{*}{ Parasitic wasps (Leucospidae, Gesteruptiidae, Chrysididae) } & Leucospis affinis & 5 & & & $\times$ \\
\hline & Gasteruption jaculator & 2 & $\times$ & & \\
\hline & Chrysis sexdentata & 2 & $\times$ & & \\
\hline Honey bees (Apidae) & Apis mellifera & 21 & & & $\times$ \\
\hline \multirow[t]{4}{*}{ Bumble bees (Apidae) } & Bombus terrestris & 8 & $\times$ & & \\
\hline & Bombus lucorum & 7 & $\times$ & & \\
\hline & Bombus argillaceus & 1 & $x$ & & \\
\hline & Bombus fragrans & 4 & $\times$ & & \\
\hline \multirow[t]{3}{*}{ Wild bees (Halictidae, Andrenidae) } & Halictus quadricinctus & 10 & & & $\times$ \\
\hline & Halictus scabiosae & 9 & & & $x$ \\
\hline & Andrena sp. & 6 & & & $\times$ \\
\hline \multirow[t]{10}{*}{ Hoverflies (Syrphidae) } & Eristalis tenax & 12 & & & $x$ \\
\hline & Eristalis arbustorum & 9 & & & $x$ \\
\hline & Eristalis interruptus & 3 & & & $x$ \\
\hline & Myathropa florea & 6 & & & $\times$ \\
\hline & Cheilosia pallipes & 6 & & & $\times$ \\
\hline & Volucella zonaria & 4 & & $x$ & \\
\hline & Eupeodes corollae & 9 & & & $\times$ \\
\hline & Merodon tricinctus & 5 & & & $x$ \\
\hline & Sphaerophoria scripta & 7 & & & $x$ \\
\hline & Melanostoma millenium & 10 & & & $x$ \\
\hline
\end{tabular}


Table 1 (continued)

\begin{tabular}{|c|c|c|c|c|c|}
\hline \multirow[t]{2}{*}{ Insect group } & \multirow[t]{2}{*}{ Species name } & \multirow[t]{2}{*}{$n$} & \multicolumn{3}{|c|}{$\begin{array}{l}\text { Captured on the functional } \\
\text { stage }\end{array}$} \\
\hline & & & Male & Female & Both \\
\hline \multirow[t]{6}{*}{ Tachinid flies (Tachinidae) } & Cylindromyia intermedia & 8 & & & $\times$ \\
\hline & Cylindromyia bicolor & 2 & & & $x$ \\
\hline & Tachina sp. 1 & 1 & & $\times$ & \\
\hline & Tachina sp. 2 & 1 & & $x$ & \\
\hline & Sarcophaga sp.1 & 1 & & $\times$ & \\
\hline & Sarcophaga sp. 2 & 1 & & $\times$ & \\
\hline \multirow{8}{*}{$\begin{array}{l}\text { Beetles (Cleridae, Coccinellidae, Cantharidae, Scarabaeidae, } \\
\text { Cetoniidae, Cerambycidae) }\end{array}$} & Trichodes apiarius & 6 & $x$ & & \\
\hline & Coccinella septempunctata & 4 & $x$ & & \\
\hline & Coccinella quatuordecimpustulata & 4 & & & $\times$ \\
\hline & Adalia bipunctata & 4 & & & $x$ \\
\hline & Rhagonycha fulva & 5 & $x$ & & \\
\hline & Cetonia aurata & 4 & & & $x$ \\
\hline & Oxythyrea funesta & 2 & $x$ & & \\
\hline & Chlorophorus varius & 5 & $x$ & & \\
\hline Net wings (Chrysopidae) & Chrysoperla carnea & 1 & $x$ & & \\
\hline
\end{tabular}

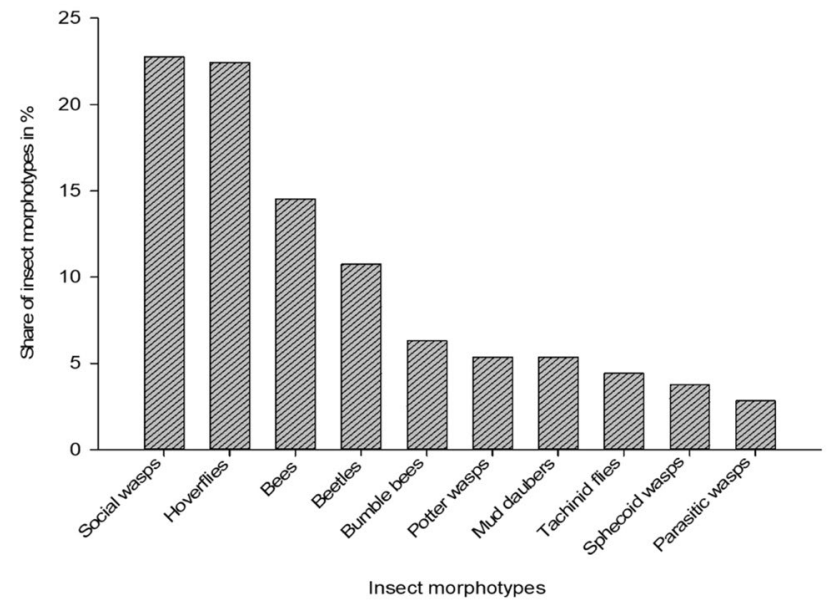

Fig. 1 Frequencies of different insect groups attracted by $F$. vulgare. Data based on sample collections in years 2009-2010 ( $n=312$ specimens)

the duration of days from the start of the flowering period was different between fennels' functional stages $(t=-33.11$; $d f=597.94 ; p<0.0001)($ Mean \pm SD: $23.71 \pm 1.41: n=600$, Fig. 2). Male umbels were mass flowering nearly 25 th day from the beginning of the flowering season (modelbased mean number of days \pm Cls: male functional stage: $25.04 \pm 1.18: n=427)$. In the studied sample any functionally active female umbel of 1st or 2 nd order was recorded before 34th day from the beginning of flowering season (Min $=34, \operatorname{Max}=56$ ) and the mass flowering peak for that

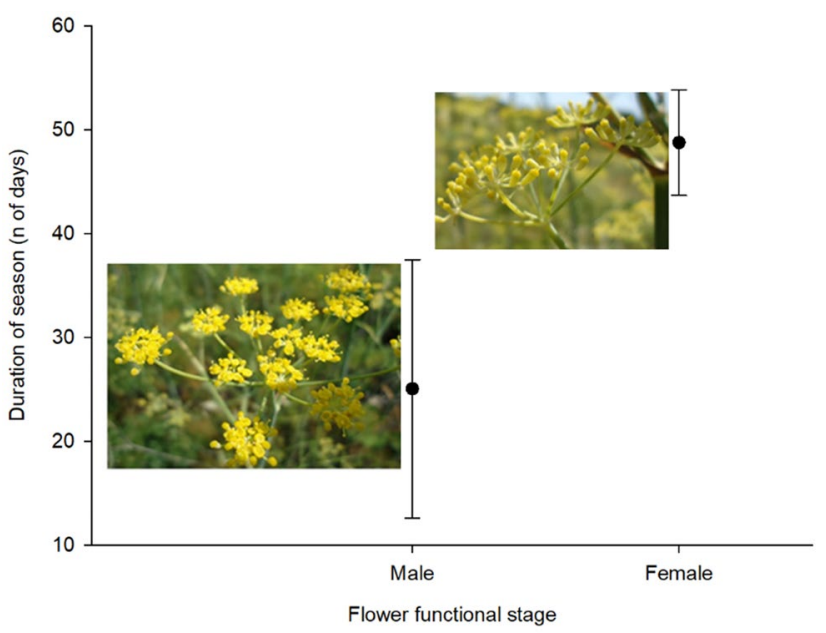

Fig. 2 Mean difference (Mean \pm SD) in the number of days from the beginning of $F$. vulgare flowering season between male and female functional stages. Mean values are obtained from the $t$-test ( $T$ test procedure in SAS; $n=600$ )

stage was around 48th day (model-based mean number of days \pm Cls: female functional stage: $48.75 \pm 0.76: n=173$ ).

When revealing the difference in insects' visitation between male and female functional stages, the significant results were obtained for bees, bumble bees, and beetles, but not for wasps and flies (Table 2).

GLM analyses revealed that the duration of fennel's flowering season significantly affected presence of all five 
Table 2 Difference in insects visitation (Mean visits $\pm \mathrm{SD}$ ) between $F$. vulgare male and female functional stages ( $T$ test procedure in SAS)

\begin{tabular}{|c|c|c|c|c|c|c|c|}
\hline \multirow[b]{2}{*}{ Insect group } & \multirow[b]{2}{*}{$t$} & \multirow[b]{2}{*}{$d f$} & \multirow[b]{2}{*}{$p$} & \multicolumn{2}{|c|}{ Male stage } & \multicolumn{2}{|c|}{ Female stage } \\
\hline & & & & $n$ & Mean \pm SD & $n$ & Mean \pm SD \\
\hline Wasps & 2.5 & 598 & 0.012 & 427 & $3.1 \pm 1.5$ & 173 & $2.7 \pm 1.7$ \\
\hline Bees & 5.9 & 598 & $<0.005$ & 427 & $2.1 \pm 1.4$ & 173 & $1.3 \pm 1.3$ \\
\hline Bumble bees & 31 & 426 & $<0.005$ & 427 & $1.7 \pm 1.1$ & 173 & - \\
\hline Beetles & 6.2 & 591 & $<0.005$ & 427 & $0.6 \pm 1.1$ & 173 & $0.2 \pm 0.5$ \\
\hline Flies & -1.7 & 598 & 0.702 & 427 & $2.9 \pm 1.7$ & 173 & $3.2 \pm 1.6$ \\
\hline
\end{tabular}

Significant $p$ values are marked as bold
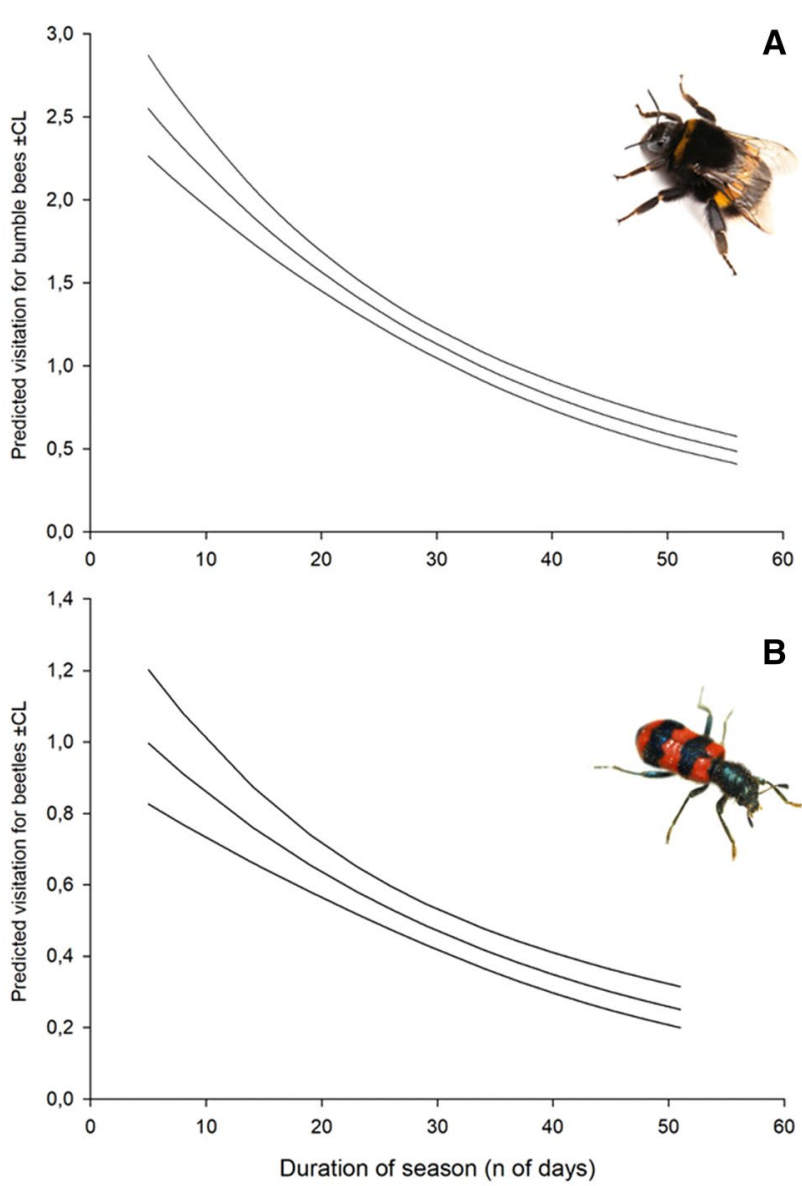

Fig. 3 Predicted visitation \pm CL for bumble bees (a) and beetles (b), affected by the duration of fennel's flowering season (obtained from the GLM model; $n=600$ observations)

insect groups on umbels, however in different ways. With the continuation of season there was a noticeable decrease in bumble bees $\left(\chi^{2}=172.78, d f=1, p<0.0001\right.$, Fig. 3a) and beetles $\left(\chi^{2}=61.03, d f=1, p<0.0001\right.$, Fig. 3b). Presence of bees $\left(\chi^{2}=12.12, d f=1, p=0.0005\right.$, Fig. 4a) and wasps $\left(\chi^{2}=8.84, d f=1, p=0.003\right.$, Fig. $\left.4 \mathrm{~b}\right)$ were also decreasing towards the end of the season but to a lesser extent than bumble bees and beetles. Contrastingly, there
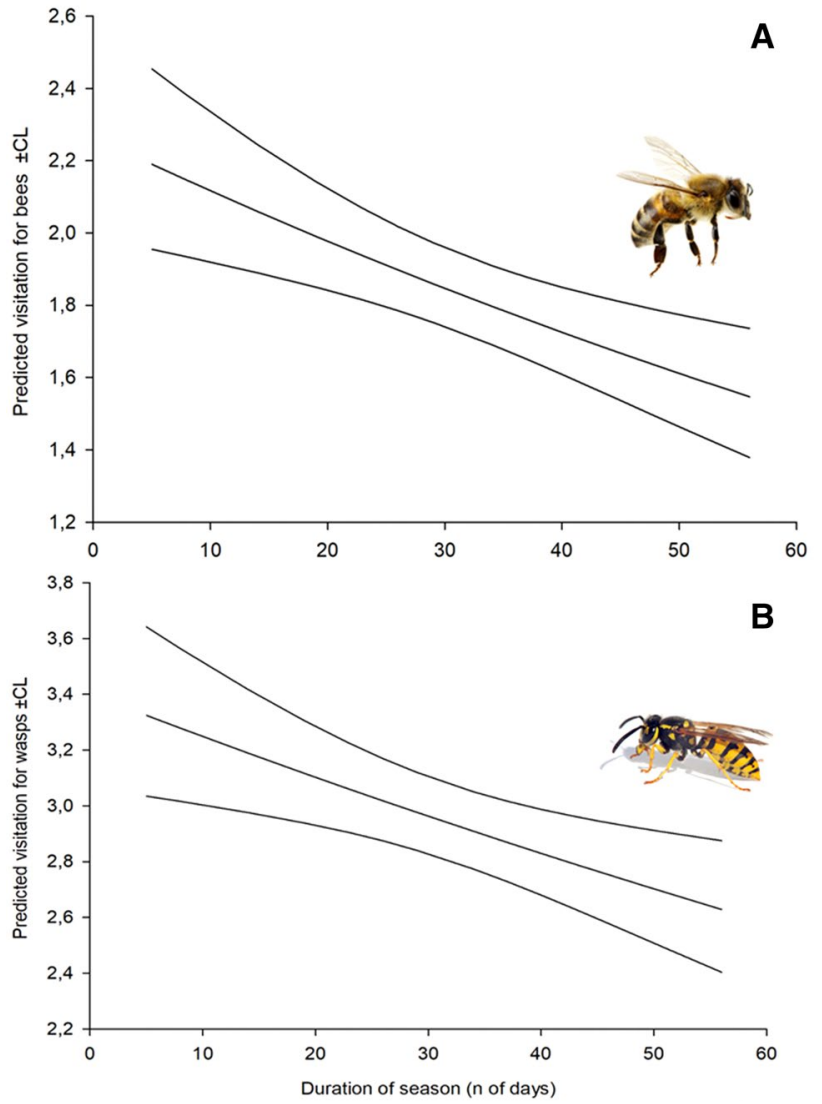

Fig. 4 Predicted visitation \pm CL for bees (a) and wasps (b), affected by the duration of fennel's flowering season (obtained from the GLM model; $n=600$ observations)

was an increase in flies' visits towards the end of fennels' flowering season $\left(\chi^{2}=8.58, d f=1, p=0.0034\right.$, Fig. 5).

\section{Discussion}

\section{Insect diversity and attraction by fennel}

Results of the current study demonstrate that fennel attracts taxonomically diverse insect fauna. This is consistent with the previous results obtained for the other umbellifers (Ricciardelli D'albore 1986; Maingay et al. 1991; 


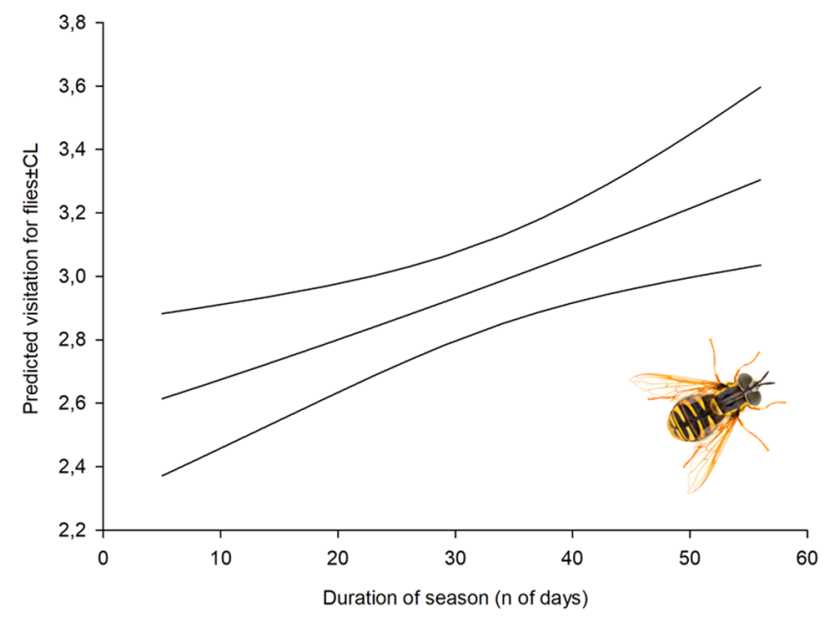

Fig. 5 Predicted visitation \pm CL for flies, affected by the duration of fennel's flowering season (obtained from the GLM model; $n=600$ observations)

Zych 2007; Zych et al. 2007) and with the study about fennel as an isolation buffer between organic and conventional production areas (Ugrenović et al. 2012). In Crimea major groups of visitors comprised hymenopterans, dipterans and coleopterans. Interestingly, during the 2 nd year of observations, it was found that fennel was a feed plant for the old world swallowtail butterfly Papilio machaon, as two larvae of this species were found. Wehling and Thompson (1997) reported that in North America F. vulgare was a very common host plant for anise swallowtail butterfly Papilio zelicaon. My data demonstrate that during 2 study years lepidopterans were not registered as visitors in Crimea. Neuropterans were present but rare. However, $F$. vulgare was shown as a beneficial plant for the fecundity of Chrysoperla carnea (Neuroptera, Chrysopidae), which is an important agent of biological control (Gonzalez et al. 2016). Current data on the insect diversity of $F$. vulgare allow considering it as a potential magnet species with further comparison between its entomofauna and that of the neighboring plants.

The key attractants of flowers are volatiles, color, architecture and availability of reward (nectar or pollen) (Bronstein et al. 2006; Miller et al. 2011). Key odorants of fennel are trans-Anethole, estragole, fenchone, $p$-anisaldehyde and cis-anethole (Diäaz-Maroto et al. 2005). Conspicuous greenish-yellow tint of fennel's petal is among the most attractive colors for pollinators (Faegri and Van Der Pijl 2016). Flowers with nectaries that are completely exposed are attractive to taxonomically diverse groups of insects (Bronstein et al. 2006). Due to all these factors, fennel is a highly attractive species to diversity of insects A plant, which is pollinated by a large number of taxonomically diverse species, follows a generalist plant strategy or simply is called a "generalist" plant (Menz et al. 2011). However, flower visitation does not necessarily lead to pollination (Memmott 1999). Frequently umbellifers, that receive a diversity of visitors can have a limited number of real pollinators (Niemirsky and Zych 2011); and the range of true pollinators of $F$. vulgare has not been yet revealed.

Two prevalent groups, which dominated in sample collections, were social wasps (Vespidae) and hoverflies (Syrphidae). Carnivorous larvae of both social wasps and many hoverflies (which can also be saprophagous or phytophagous) require proteins from prey insects, while adults feed on carbohydrates and search for nectar on plants (Gilbert 1981; Hemptinne et al. 1993; Richter 2000). Therefore, they can act as both predators and pollinators. For example, Polistes wasps were effectively used to protect crops from lepidopteran pests (Gould and Jeanne 1984; Southon et al. 2019) and larvae of a hoverfly Episyrphus balteatus were able to suppress aphid colony growth (van Rijn et al. 2013). Hoverflies are among the most important groups of wild pollinators globally (Rader et al. 2016). Polistes and Vespula wasps can make an essential contribution to plant pollination too. In Crimea it was found that the rare and endangered orchids such as broad-leaved helleborinae (Epipactis helleborine), steveniella (Steveniella satyrioides) and bug orchid (Orchis coriophora) were pollinated by social wasps (Ivanov et al. 2015). Other Crimean orchids from the genus Epipactis were also largely dependent on the pollination service provided by Vespidae wasps (Fateryga and Ivanov 2012).

Besides social wasps and hoverflies fennel attracted honey bees, wild bees and bumble bees, beetles, various groups of wasps and flies. Most of those are beneficial pollinators (Rader et al. 2016) and some are important agents for biological control being predators and parasitoids (Lopez et al. 2013; Wang et al. 2019).

The insect community found in this study differs from that associated with fennel found in other parts of the specie's range. In India honey bees were the predominant group of insects visiting $F$. vulgare, following by wasps and flies (Chaudhary 2006; Shilpa et al. 2014). However, research by Shilpa et al. (2014) recorded only 16 insect species. Studies conducted in Czech Republic suggested that fennel attracts pronominally ladybeetles and hoverflies, and therefore it can be included as a beneficial plant to flower strips (Kopta et al. 2012). Further data about insects associated with $F$. vulgare in different geographic areas will benefit revealing of the community structure at a broader scope.

\section{Insect dynamics}

Across a range of fennel's distribution, there might be variation in the duration of its flowering season. In Crimea fennel was in bloom around 9 weeks, while in the USA 
flowering period was reported to be 12 weeks (Maingay et al. 1991). Results of the current study revealed that at the population level there was a difference in the duration of male and female functional stages. There was significant bias towards the male functional stage, which lasted for about 23 days longer than the female stage. It has been previously found that in dichogamous species nectar production if often different between sexual stages. For example, in Angelica sylvestris it was three times lower during the stigma receptive period (Stpiczyńska et al. 2015). Therefore, it is more likely that due to functional protandry and different floral nectar production between sexual phases, not all insects visit both types of flowering umbels. Results of the current study confirm that at least visitation by bees, bumble bees and beetles differ between $F$. vulgare sexual stages. My data also demonstrate that during the flowering season number of bumble bee and beetle visitation decreased after the end of the mass flowering male stage. Wasps and bees were also decreasing towards the season end, however not so rapidly. Contrary to the other groups, the number of fly visitation was increasing towards the season end. Interestingly, medium-size flies were revealed to be the most important pollinators for the Umbeliferrae plant Heracleum sphondylium (Zych 2007). So, it is more likely that hoverflies significantly contribute to pollination of fennel.

The most significant plant-insect mutualistic interactions include pollination, protection and seed dispersal (Bronstein et al. 2006). By attracting diverse insect species, fennel can benefit other plant species and indirectly favor ecosystem services. Current management schemes described as pollinator friendly management techniques appear to benefit the restricted number of aculeate species, mainly honey bees and bumble bees (Wood et al. 2015). Therefore, careful selection of the ways and methods of attracting beneficial insects will contribute to creation better habitat types. High-quality ecosystem services can be provided by insects in habitats with enough resources. Using $F$. vulgare in creation of wildflower stripes and restoration projects will favor attraction of diverse beneficial insects and will promote the overall conservation of plant-insect mutualistic interactions.

Acknowledgements Open access funding provided by University of Eastern Finland (UEF) including Kuopio University Hospital. Most of my gratitude is dedicated to late Nikolay Kuznetsov, who supported the initial idea of this study. I am thankful to Alexander Fateryga for identification species belonging to solitary wasp group (Eumenidae), help with identification of some other Hymenoptera species and useful comments on the early version of the manuscript. Irina Lyshenina kindly provided identification of Diptera species. I am grateful to Kristina Brester for statistics tips, Jouni Sorvari for the useful comments and to Patrick Grof-Tisza for English language editing and valuable comments on the current version of the manuscript.
Funding The study was financially supported by the doctoral program of Nikitsky Botanical Garden-National Scientific Center (Yalta, Crimea). Photos for Figure 2 were taken by the author. Insect pictures used in Figures 3-5 were purchased with the Standard License from Shutterstock Inc.

\section{Compliance with ethical standards}

Conflict of interest The author declares that they have no conflict of interest.

Open Access This article is licensed under a Creative Commons Attribution 4.0 International License, which permits use, sharing, adaptation, distribution and reproduction in any medium or format, as long as you give appropriate credit to the original author(s) and the source, provide a link to the Creative Commons licence, and indicate if changes were made. The images or other third party material in this article are included in the article's Creative Commons licence, unless indicated otherwise in a credit line to the material. If material is not included in the article's Creative Commons licence and your intended use is not permitted by statutory regulation or exceeds the permitted use, you will need to obtain permission directly from the copyright holder. To view a copy of this licence, visit http://creativecommons.org/licenses/by/4.0/.

\section{References}

Allsopp MA, de Lange WJ, Veldtman R (2008) Valuing insect pollination services with cost of replacement. PLoS ONE 3(9):e3128

Altieri MA (1991) How best can we use biodiversity in agroecosystems. Outlook Agric 20:15-23

Badgujar SB, Patel VV, Bandivdekar AH (2014) Foeniculum vulgare Mill.: a review of it's botany, phytochemistry, pharmacology, contemporary application, and toxicology. BioMed Res Int. https:// doi.org/10.1155/2014/842674

Bronstein JL, Alarcon R, Geber M (2006) The evolution of plant-insect mutualisms. New Phytol 172:412-428

Campbell AJ, Biesmeijer JC, Varma V, Wäckers FL (2012) Realizing multiple ecosystem services based on the response of three beneficial insect groups to floral traits and trait diversity. Basic Appl Ecol 13:363-370

Chaudhary OP (2006) Diversity, foraging behaviour of floral visitors and pollination ecology of fennel (Foeniculum vulgare Mill.). J Spic Aromat Crops 15(1):34-41

Courchamp F, Berec L, Gascoigne J (2008) Allee effects in ecology and conservation. Oxford University Press, Oxford, New York, p 272

Diäaz-Maroto MC, Diäaz-Maroto Hidalgo IJ, Sanchez Palomo E, Perez-Coelo MS (2005) Volatile components and key odorants of fennel (Foeniculum vulgare Mill.) and thyme (Thymus vulgaris L.) oil extracts obtained by simultaneous distillation-extraction and supercritical fluid extraction. J Agric Food Chem 53:5385-5389

Faegri K, Van Der Pijl L (2016) Principles for pollination ecology, 3rd edn. Pergamon, Oxford, p 256

Fateryga AV, Ivanov SP (2012) Pollination ecology of the species from the genus Epipactis (Orchidacea) in the Crimea. Ecosyst Optim Secur 6:136-150 (In Russian)

Ghazoul J (2006) Floral diversity and the facilitation of pollination. J Ecol 94:295-304

Gilbert FS (1981) Foraging ecology of hoverflies: morphology of the mouthparts in relation to feeding on nectar and pollen in some common urban species. Ecol Entomol 6(3):245-262

Goldstein J, Zych M (2016) What if we lose a hub? Experimental testing of pollination network resilience to removal of keystone floral resources. Arthropod Plant Interact 10:263-271 
Gonzalez D, Nave A, Gonçalves F, Nunes FM, Campos M, Torres L (2016) Higher longevity and fecundity Chrysoperla carnea, a predator of olive pests, on some native flowering Mediterranean plants. Agronom Sustain Dev 36:30

Gould WP, Jeanne RL (1984) Polistes wasps (Hymenoptera: Vespidae) as control agents for Lepidopterous cabbage pests. Environ Entomol 13(1):150-156

Hemptinne J-L, Dixon AFG, Doucet J-L, Petersen J-E (1993) Optimal foraging by hoverflies (Diptera: Syrphidae) and ladybirds (Coleoptera: Coccinellidae): mechanisms. Eur J Entomol 90:451-455

Ivanov SP, Kholodov VV, Fateryga AV (2015) Crimean orchids: pollination composition, pollination systems diversity and its effectiveness. Sci Notes Taur Nati V.I. Vernadsky Univ 22 (61):24-34

Kopta T, Polkuda R, Psota V (2012) Attractiveness of flowering plants for natural enemies. Hortic Sci 39(2):89-96

Laverty TM (1992) Plant interactions for pollinator visits: a test of the magnet species effect. Oecologia 89:502-508

Letourneau DK, Armbrecht I, Rivera BS, Lerma JM, Carmona EJ, Daza MC, Escobar S, Galindo V, Gutiérrez C, López SD, Mejía JL, Rangel AM, Rangel JH, Rivera L, Saavedra CA, Torres AM, Trujillo AR (2011) Does plant diversity benefit agroecosystems? A synthetic review. Ecol Appl 21(1):9-21

Lopez L, Armbrecht I, Montoya-Lerma J, Molina YS (2013) Diversity of parasitoid wasps in an organic sivopastoral system for cattle production in Columbia. Avanc Investig Agropec 17(1):65-78

Maingay HM, Bugg RL, Carlson RW, Davidson NA (1991) Predatory and parasitic wasps (Hymenoptera) feeding at flowers of sweet fennel (Foeniculum vulgare Miller var. dulce Battandier \& Trabut, Apiaceae) and spearmint (Mentha spicata L., Lamiaceae) in Massachusetts. Biol Agric Hortic 7(4):363-383

Memmott J (1999) The structure of a plant-pollinator food web. Ecol Lett 2:276-280

Menz MHM, Phillips RD, Winfree R, Kremen C, Aizen MA, Johnson SD, Dixon KW (2011) Reconnecting plants and pollinators: challenges in the restoration of pollination mutualisms. Trends Plant Sci 16(1):4-12

Miller R, Owens SJ, Rørslett B (2011) Plants and colour: flowers and pollination. Opt Laser Technol 43:282-294

Niemirsky R, Zych M (2011) Fly pollination of dichogamous Angelica sylvestris (Apiaceae): how (functionally) specialized can a (morphologically) generalized plant be? Plant System Evol 294:147-158

Noriega JA, Hortal J, Azca'rate FM, Berg MP, Nuria B, Briognes MJI, Del Toro I, Goulson D, Ibanez S, Landis DA, Moretti M, Potts SG, Slade EM, Stout JC, Ulyshen MD, Wackers FL, Woodcock BA, Santos AMC (2018) Research trends in ecosystem services provided by insects. Basic Appl Ecol 26:8-23

Piccaglia R, Marotti M (2001) Characterization of some Italian types of wild fennel (Foeniculum vulgare Mill.). J Agric Food Chem 49:239-244

Potts SG, Biesmeijer JC, Kremen C, Neumann P, Schweiger O, Kunin WE (2010) Global pollinator declines: trends, impacts and drivers. Trends Ecol Evol 25(6):345-353

Rader R et al (2016) Non-bee insects are important contributors to global crop pollination. PNAS 113(1):147
Ricciardelli Dalbore GC (1986) Les insectes pollinisateurs de quelques ombelliferes d'intéret agricole et condimentaire (Angelica archangelica L., Carum carvi L., Petroselinum crispum A.W. Hill, Apium graveolens L., Pimpinella anisum L., Daucus carota L., Foeniculum vulgare Miller V., Azoricum Thell.). Apidologie 17(2):107-124

Richter MR (2000) Social wasps (Hymenoptera: Vespidae) foraging behavior. Annu Rev Entomol 45:121-150

Sánchez-Bayo F, Wyckhuys KAG (2019) Worldwide decline of entomofauna: a review of its drivers. Biol Conserv 232:8-27

Scherr SJ, McNeely J (2008) Farming with nature: the science and practice of ecoagriculture. Island Press, Washington, $\mathrm{p} 472$

Shilpa P, Sowmya KS, Srikanth CD, Kuberappa GC (2014) Pollinator diversity and foraging activity on fennel, Foeniculun vulgare Mill. and African marigold, Tagetus minuta L. Pest Manag Hortic Ecosyst 20(2):236-239

Southon RJ, Fernandes OA, Nascimento FS, Sumner S (2019) Social wasps are effective biocontrol agents of key lepidopteran crop pests. Proc R Soc B 286:20191676

Stpiczyńska M, Nepi M, Zych M (2015) Nectaries and male-biased nectar production in protandrous flowers of a perennial umbellifer Angelica sylvestris L. (Apiaceae). Plant Syst Evol 301:1099-1113

Ugrenović V, Filipović V, Glamočlija D, Subić J, Kostić MB, Jevđović R (2012) Benefits of using fennel as isolation buffer in organic agriculture. Ratar Povrt 49:126-131

van Rijn PCJ, Kooijman J, Wäckers FL (2013) The contribution of floral resources and honeydew to the performance of predatory hoverflies (Diptera: Syrphidae). Biol Control 67:32-38

Wäckers FL, van Rijn PC (2012) Pick and mix: selecting flowering plants to meet the requirements of target biological control insects. In: Geoff MG, Wratten SD, Snyder WE (eds) Biodiversity and insect pests: key issues for sustainable management. Wiley-Blackwell, New Jersey, pp 139-165

Wang Z-Z, Liu Y-Q, Shi M, Huang J-H, Chen X-X (2019) Parasitoid wasps as effective biological control agents. J Integr Agric 18(4):705-715

Webb CJ (1981) Andromonoecism, protandry, and sexual selection in Umbelliferae. New Zeal J Bot 19:335-338

Wehling WF, Thompson JN (1997) Evolutionary conservatism of oviposition preference in a widespread polyphagous insect herbivore, Papilio zelicaon. Oecologia 111:209-215

Wood TJ, Holland JM, Goulson D (2015) Pollinator-friendly management does not increase the diversity of farmland bees and wasps. Biol Conserv 187:120-126

Zych M (2007) On flower visitors and true pollinators: the case of protandrous Heracleum sphondylium L. (Apiaceae). Plant System Evol 263:159-179

Zych M, Niemczyk P, Niemirsky R (2007) Umbellifers as potential keystone species in restoration projects. Acta Agrobotan 60(2):45-49

Publisher's Note Springer Nature remains neutral with regard to jurisdictional claims in published maps and institutional affiliations. 